\title{
REPRODUCTION OF WORKS FOR PRIVATE USE
}

\author{
Ingrida Veiksa*
}

\begin{abstract}
Access to the works on Internet is subject to the same general conditions for the use of copyright protected works-the use without permission is not allowed! However, this provision is "not working", because in so called "information society" where anyone can easy access to the works placed on the world wide web (music, literature, sound recordings, films, television and radio programs etc.) and use them in different ways: view, download (reproduce) on computer, print, send to friend etc. Nowadays, the environment where authors' works are used has significantly changed, and it would be appropriate to change the copyright system so that it would suit better to interests and concepts of modern people. That way the copyright protection would be updated taking into consideration both the authors' interests and the information society's right to access the scientific and art accomplishments.
\end{abstract}

INTRODUCTION

I. EXISTING INFRINGEMENT OF AUTHOR'S REPRODUCTION RIGHT 415 II. AUTHOR's RIGHT TO GET REMUNERATION FOR REPRODUCTION OF WORK

III. TRENDS OF DEVELOPMENT OF LIMITATION TO REPRODUCTION RIGHTS419

A. Opinion of European Commission 419

B. Findings of European Union Court of Justice. 422 CONCLUSION 423

\section{INTRODUCTION}

Access to the works on Internet is subject to the same general conditions for the use of copyright protected works - the use without permission is not allowed! However, this provision is "not working", because in so called "information society" where anyone can easy access to the works placed on the world wide web (music, literature, sound recordings, films, television and radio programs etc.) and use them in different ways: view, download (reproduce) on computer, print, send to friend etc. In today's society, almost everyone has once "taken" from the Internet (you tube, torrents, google, e-library, etc.) a lovely song, a new movie, a photograph or a book, downloaded it to the computer, shared with others or used in any other way. In society, it is considered to be quite normal behavior, and hardly anyone condemns it. But according to law-use of

\footnotetext{
* Dr.iur, Head of Law Department, Professor, Turiba University, Riga, Latvia. Research fields: intellectual property, copyright, information society.
} 
copyright protected work without the permission of the author is infringement of rights!

If the author himself has posted his work on Internet, it is considered that, he himself has made it available to the public, so-allowed its use. However, the vast majority of cases it is not the author himself, but the other person who does not have any rights in particular work. Consequently wethe society, who effortlessly find these works on the Internet, are not entitled to use them.

In the fight against this kind of unauthorized, use of copyright protected works are involved a number of law enforcement institutions, which catch, investigate, accuse, judge, enforce the sentence, it has been a number of convictions, but the situation has not improved!

\section{EXISTING INFRINGEMENT OF AUTHOR’S REPRODUCTION RIGHT}

Nowadays, according to the law of many countries, individuals (consumers ${ }^{1}$ ) are allowed to make one copy of work from legally acquired tangible medium to create their own copy for personal needs by paying so called "blank type levy". However, by the fast development of technologies, the Internet offers the growing variety of copyright protected contentwhich is placed there not always legally. This content is very rich, and members of society would love to read, listen, watch and download (reproduce) it on the self-owned recording media - computer hard drives, flash drives, phones, etc.

Every minute people upload around 72 hours of video to YouTube, and over 150,000 photos to Facebook. Sometimes this user-generated content "re-uses" existing material (such as re-mixes, mashups and home-made videos with a soundtrack added) and so is often covered by some form of licensing by rights holders, in partnership with certain platforms, but this is not transparent to the end user ${ }^{2}$.

The precondition for the legality of private copying is requirement to copy only from a legal source. When work is uploaded on Internet without consent of author, consequently - it cannot be legally downloaded, as source is not legal. It is difficult to imagine that, any exception that countenances copying works which have acquired or accessed illegally, would pass the

\footnotetext{
${ }^{1} 2000$ Latvia Copyright Law, LATVIJAS VĒstnesis (2000), No. 148/150. Section 34. Blank Tape Levy.

${ }^{2}$ European Commission Urges Industry to Deliver Innovative Solutions for Greater Access to Online Content, (Brussels: December 18, 2012). Available at http://europa.eu/rapid/press-release IP-121394_en.htm (last visited April 24, 2016).
} 
three step test ${ }^{3}$. So-reproduction, paying a "blank type levy" is not recognized as a legal action, if the material has been made available to the public without permission of the rights holders (authors, performers, film and phonogram producers, broadcasting organizations). Consequently-one of the areas not covered by the exceptions and limitations, is limitation to make copies from the source which is not always legal.

But first has to be explored what is the existing legal framework at the international, European Union and national level, and then to search for ways how this framework can be further developed.

\section{AUTHOR's RIGHT TO GET REMUNERATION FOR REPRODUCTION OF WORK}

According to the Copyright Law of all civilized countries, author has the right to allow or prohibit use of his work, and is entitled to receive a remuneration.

According to the Peter Groves - reproduction is an act restricted by copyright, dealt with Article 8 of the Berne convention, which does not clarify the meaning of the word save to say that any manner or form is covered. $^{4}$

It was pointed as well by Dr. Francis Gurry (Director General of WIPO) - in future the two hitherto known funding models of authors (ancient patronage or modern copyright) will change, and new model must be invented, since digital era has brought too much new developments ${ }^{5}$. Professor Lawrence Lessig (Stenford University) believes the assumption that, intellectual property needs maximum protection leads us along the wrong path. No doubt intellectual property rights is the best way to further innovation; however it is permissible with the condition that, there is a balance between the public area and private property. When the Internet was first born, its initial architecture effectively tilted in the "no rights reserved" direction. Content could be copied perfectly and cheaply; rights could not easily be controlled. Any rights were effectively unprotected. This initial character produced a reaction (opposite, but not quite equal) by copyright owners. Through legislation, litigation, and changes to the network's design, copyright holders have been able to change the essential character of the environment of the original Internet. If the original architecture made the effective default "no rights reserved", the future architecture will make the

\footnotetext{
${ }^{3}$ B. LindNER AND T. SHAPIRO, COPYRIGHT IN THE INFORMATION SOCIETY 328 (Edward Elgar Publishing 2011).

${ }^{4}$ Groves P., A Dictionary of Intellectual Property Law 268 (Cheltenham, UK: Edward Elgar 2011).

${ }^{5}$ Conference “Intellectual Property Rights Management” (Riga, Latvia: May 8-9, 2012).
} 
effective default "all rights reserved". The architecture and law that surround the Internet's design will increasingly produce an environment where all use of content requires permission ${ }^{6}$.

European Commission already in year 2009 initiated discussion of creating in Europe a modern, pro-competitive, and consumer-friendly legal framework for a genuine Single Market for Creative Content Online, in particular by:

(1) protection of rights of authors (by creating a favorable environment in the digital world for creators and rightholders, by ensuring appropriate remuneration for their creative works, as well as for a culturally diverse European market);

(2) strengthening the competition in business (by promoting a level playing field for new business models and innovative solutions for the distribution of creative content);

(3) ensuring the interests of society (by encouraging the provision of attractive legal offers to consumers with transparent pricing and terms of use, thereby facilitating users' access to a wide range of content through digital networks anywhere and at any time). ${ }^{7}$

Intellectual property researcher from Germany Mr. Tim Kreutzer in his lecture in Goethe Institute in Riga, Latvia on February 24, 2010 pointed out that, one of the basic principles in copyright law is the legal protection of the author: the composer of a song, the filmmaker or software programmer is protected from unauthorized use of their created products. This involves, firstly, to his personal relationship to the respective work, but then also to its economic interests in their use. The author should benefit from any commercial exploitation of his/her work ${ }^{8}$.

Professor James Boyle (Duke Law School) holds a view that, intellectual property protection has expanded exponentially in breadth, scope and term over the last 30 years, and the fundamental principle of balance between the public domain and the realm of property seems to have been lost. In the professor's opinion, the copyright term limits are now absurdly long - the most recent retrospective extensions, to a term which already offered $99 \%$ of the value of a perpetual copyright, had the practical

\footnotetext{
${ }^{6}$ L. Lessig, Free Culture: How Big Media Uses Technology and the Law to Lock down Culture and Control Creativity, 276-277 (New York: The Penguin Press 2004).

${ }^{7}$ Creative Content in a European Digital Single Market: Challenges for the Future, A REFLECTION DOCUMENT OF DG INFSO AND DG MARKT 3 (October 22, 2009). Available at $\mathrm{http}: / /$ ec.europa.eu/archives/information_society/avpolicy/docs/other_actions/col_2009/reflection_pap er.pdf (last visited October 10, 2014).

${ }^{8}$ T. Kreutzer, The Origin, Status and Future of Copyright (Riga, Latvia: Lecture in Goethe Institute, February 24, 2010).
} 
effect of helping a tiny number of works that are still in print, or in circulation, and it is between $1 \%$ and $4 \%{ }^{9}$. Professor Yoav Mazeh (Wolfson College, Oxford) observes that, copyright law has always tried to balance the need for incentives for creativity, on the one hand, and the need to enable society to access works which have been created, on the other. Broadening the protection provided by copyright provides greater incentives for authors, but narrows the public domain, that is, the common cultural resources to which the public has access. Finding the right balance between sufficient incentives for creativity and over-restricting the public domain has always been, and still is, one of the main challenges of copyright law ${ }^{10}$.

Writer Marjorie Heins (founder of the Free Expression Policy Project) holds a view that, copyright law is a tricky balancing act. The problem with this is that, it ignores the critical pivot on which copyright law is built - the balance between monopoly control and free expression, and fair use is especially important in enriching our culture because it encourages new works ${ }^{11}$. Professor Michael Geist (University of Ottawa Law School) emphasizes the dangers of copyright that veers too far toward copyright creators at the expense of the public. He notes that, excessive control by holders of copyrights and other forms of intellectual property may unduly limit the ability of the public domain to incorporate and embellish creative innovation in the long-term interests of society as a whole, or create practical obstacles to proper utilization ${ }^{12}$.

Till Kreutzer considers that, copyright system is removed from the protection of creative works supporting to the protection of economic interests of the industry exploiting the work. Reforms at the political level have often stated that, they wanted to strengthen the rights of copyright holders, but in many cases, it is only to interests of the industry exploiting the work. In the past, copyright was a law for professionals-for authors and publishers of books, record and film industry. Today, there are legal amateurs on the Internet who are in contactwith copyright issues almost every day. Therefore copyright has become a law regulating the general behavior of the society. However, it is much too complex to use for this

\footnotetext{
${ }^{9}$ J. Boyle, A Manifesto on WIPO and the Future of Intellectual Property, DuKE LAW SCHOOL \& TeChNOlogy ReVIEw (2004), Nr. 9. Available at http://www.law.duke.edu/journals/dltr/articles/2004dltr0009.html (last visited September 22, 2008).

${ }^{10}$ Y. Mazeh, Present AND Future Priorities In COPYRIGHT Law. Available at http://www.ipinstitute.org.uk/ipacreport1.doc (last visited February 16, 2011).

${ }^{11}$ M. Heins, Trashing the Copyright BALANCE (September 21, 2004). Available at http://www.fepproject.org/commentaries/bridgeport.html (last visited February 16, 2016).

${ }^{12}$ M. Geist, Key Case Restores Copyright Balance. Available at http://www.michaelgeist.ca/content/view/181/77 (last visited February 16, 2016).
} 
purpose and difficult to enforce because of its outdated conception ${ }^{13}$. The librarian David Gee (University of London) with more than eighteen years experience working in academic law libraries considers that, there are still many copyright "hot topics" to be addressed before this "copyright balance" is achieved, and it remains to be seen whether the current UK government will be minded to support the alterations to national copyright legislation that, librarians are lobbying for both in UK and in other jurisdictions ${ }^{14}$. Nowadays we see that, UK has adopted a number of amendments in its Copyright, Designs and Patents Act ${ }^{15}$, which among other things makes much easier public's access to information, including that containing copyrighted works. But the question remained open - whether authors' and other rights holders' interests and the right to fair compensation has been respected?

As can be seen from the cited fragments of well-known copyright researchers - a balance should be established among right holders and the society-copyright cannot be furthered as a limitation of the freedom of acquiring the information, but authors has right of compensation for limitation of their rights.

\section{TRENDS OF DEVELOPMENT OF LIMITATION TO REPRODUCTION RIGHTS}

\section{A. Opinion of European Commission}

The issue of exceptions in the digital environment continues to be the subject of extensive discussion in Brussels and across the EU. There are even those that think that by artificially inseminating their laws with the US fair use defense, they can give birth to European Google ${ }^{16}$.

The European Commission points out, in the Memo distributed in Brussels on May 24, 2011: Reproduction fees have to be reconciled with free circulation of goods to achieve proper operation of the internal market, in order to enable undisturbed cross-border trading in goods subject to reproduction levies. Levies mean payments to be made in respect of recording devices and blank media in certain Member States, that have introduced an exception provided for in legal acts in respect of reproduction.

\footnotetext{
${ }^{13}$ T. Kreutzer, Copyright is Obsolete-Till Kreutzer Talks. Available at http://www.goethe.de/ins/lv/rig/wis/sbi/bid/lv5122599.htm (last visited February 16, 2011).

${ }^{14}$ D. Gee, A Copyright Balance? An Overview for Librarians of Current UK Copyright Law, 35(1) THE OfFicial Journal OF THE INTERNATIONAL ASSOCIATION OF LAW LibraRies 47-61 (Spring 2007).

${ }^{15}$ Copyright, Designs and Patents Act. (United Kingdom 1988). Available at http://www.legislation.gov.uk/ukpga/1988/48/contents (last visited March 28, 2016).

${ }^{16}$ B. LiNDNER AND T. SHAPIRO, COPYRIGHT IN THE INFORMATION SOCIETY (Edward Elgar Publishing 2011).
} 
Appointment of a high level independent mediator was promised in 2011 who should explore all possible approaches to approximate the methodology applicable to the fixation of levies, improve the administration of levies, in particular related to the type of devices subject to levies; fix the tariff rates, and interoperability of systems operating in different countries, taking into account the cross-border impact of different system of levies on the internal market. Coordinated efforts of all parties to resolve the still pending issues should become the fundament of comprehensive legislation measures on the EU level in $2012^{17}$.

Such comprehensive measures would include an initiative to amplify notably the concept of reproduction levy or royalty to include other forms of non-commercial use of authors' works, and such levy should be renamed to private culture-access fee. The Commission points out to the need for determining whether or not the presently applicable exceptions and restrictions imposed on copyright, in accordance with the Directive 2001/29/EC (EC, 2001) should be renewed or coordinated on the EU level. At present, according to Article 3 of the Directive, Member States shall provide authors with the exclusive right to authorize or prohibit any communication to the public of their works, by wire or wireless means, including the making available to the public of their works in such a way that, members of the public may access them from a place and at a time individually chosen by them (the Internet right). Similar to international Treaties, this Directive also provides for the possibility to impose restrictions and exceptions on the right of authors, however, unlike in case of conventions, the list presented in the Directive is exhaustive.

European Commission has already understood the need to modernize the concept of copyright in the digital environment of the information society. Development of digital media and cross-border online services opened and highlighted a number of gaps in copyright legislation and its practical application, which prevention plays an important role in establishing of a knowledge-based economy and a single digital market across the EU. European Commission has launched a number of initiatives for revision and modernization of EU copyright ${ }^{18}$. The Commission's

\footnotetext{
${ }^{17}$ Common market of intellectual property rights. Fostering of creativity and innovation to provide growth of economy, qualitative working places and high quality products and services in Europe. Commission Memo to the European Parliament, the Council, European Economic and Social Committee and Region Committee. (Brussels: May 24, 2011). ${ }^{18}$ R. Gulbis, Finding a Balance of Interests in the Digital Environment: Review of EU Copyright Rules, 2(804), 18-21 (Jurista Vārds: January 14, 2014).

${ }^{18}$ R. Gulbis, Finding a Balance of Interests in the Digital Environment: Review of EU Copyright Rules, 2(804), 18-21 (Jurista Vārds: January 14, 2014).
} 
objective is to foster transparency and ensure that end-users have greater clarity on uses of protected material. This work should identify relevant forms of licensing and how to improve information for end-users ${ }^{19}$.

European Commission has launched a public consultation as part of its on-going efforts to review and modernize EU copyright rules. The consultation invites stakeholders to share their views on following areas: territoriality in the Single Market, harmonization, limitations and exceptions to copyright in the digital age; fragmentation of the EU copyright market; and how to improve the effectiveness and efficiency of enforcement while underpinning its legitimacy in the wider context of copyright reform ${ }^{20}$. An independent set of questions in the Public Consultation questionnaire consists from questions relating to the civil liability regime on copyright infringement in activities for commercial purposes. Questions are asked about the liability of intermediaries such as Internet service provider liability, as well as ensuring a balance between the need for copyright protection and the right to privacy and protection of personal data ${ }^{21}$. Internal Market and Services Commissioner Michel Barnier said: "My vision of copyright is of a modern and effective tool that supports creation and innovation, enables access to quality content, including across borders, encourages investment and strengthens cultural diversity. Our EU copyright policy must keep up with the times" 22 .

It means that, Commission understand the need of establishing balance among different groups of rightholders and information society, and very soon new conception of copyright should come. In some countries outside European Union, legislators have already started to modernize the copyright concept for better its compliance with needs of the information society in the digital environment.

New media offer rightholders an unprecedented opportunity for disseminating their works or other protected subject matter across different platforms and for reaching out to a larger audience. In this view, easier access to creative content will have to be combined with adequate protection of rightholders in order to furnish a growing and more diverse content

\footnotetext{
${ }^{19}$ European Commission Urges Industry to Deliver Innovative Solutions for Greater Access to Online Content, (Brussels: December 18, 2012). Available at http://europa.eu/rapid/press-release_ip-121394 en.htm?locale=en (last visited April 24, 2014).

${ }^{20}$ Public Consultation on the Review of the EU Copyright Rules. Available at http://ec.europa.eu/internal_market/copyright/initiatives/index_en.htm (last visited April 24, 2014).

${ }^{21}$ R. Gulbis, Finding a Balance of Interests in the Digital Environment: Review of EU Copyright Rules, 2(804), 18-21 (Jurista Vārds: January 14, 2014).

${ }^{22}$ B. Michel, Commission Launches Public Consultation. Available at http://europa.eu/rapid/press-release_IP-13-1213_en.htm?locale=en (last visited March 24, 2016).
} 
market. Wider access to content, with more attractive business models for tackling piracy and creating new revenue streams, can only be achieved with more effective licensing mechanisms and financial incentives. More collaboration with ISPs and other companies providing access technologies would provide more options for rightholders. New business models based on access subscription rather than payment for every single work, together with advertising-supported or feelslike-free services, could become more beneficial for rightholders and ISPs. ${ }^{23}$

In the discussion on the Copyright Directive, a specific mention of Article 5.2.b should have been made, and also there should be discussion of the debate as to the scope of lawful private use in light of the recent CJEU cases. The UK could have been specifically mentioned in light of the recent legislative developments. There is also a section in the Latvian copyright act covering instances of lawful private use.

\section{B. Findings of European Union Court of Justice}

The award made by the European Union Court of Justice (EUCJ) in case of Padawan confirms that, rightholders have to receive compensation for restriction of their rights and, where such compensation is ensured by means of royalty, compensation has to be paid by those who provide reproduction devices and media to users; it is also pointed out, however, that people who make no copies cannot be expected to pay royalties. The award proves that, a rightholder has to receive compensation for restriction of rights and, where such compensation is ensured by means of royalty, compensation has to be paid by those who provide reproduction devices and media to users (in Latvia the compensation is paid by importers of blank media and reproduction devices). The possibility to make a back-up copy by means of such device or medium is treated as sufficient grounds for imposing royalty on them ${ }^{24}$.

The author of paper would share the above opinion because efforts are being taken presently to support authors in receiving compensation for use of their works for personal needs.

With regard to the legal sources for private copying the EUCJ has held

\footnotetext{
${ }^{23}$ Creative Content in a European Digital Single Market: Challenges for the Future, A REFLECTION DOCUMENT OF DG INFSO AND DG MARKT 20 (October 22, 2009). Available at http://ec.europa.eu/archives/information_society/avpolicy/docs/other_actions/col_2009/reflection_pap er.pdf. ${ }^{24}$ Judgment of the Court (Third Chamber) from October 21, 2010 in Case C-467/08, Padawan SL v. Sociedad General de Autores y Editores de España (SGAE).

${ }^{24}$ Judgment of the Court (Third Chamber) from October 21, 2010 in Case C-467/08, Padawan SL v. Sociedad General de Autores y Editores de España (SGAE).
} 
in a number of its judgments. For example, Copydan judgment has established that, the private copying permitted only from legal source. Court found that, Directive 2001/29 precludes national legislation which provides for fair compensation, in accordance with the exception to the reproduction right, in respect of reproductions made using unlawful sources, namely from protected works which are made available to the public without the rightholder's consent. ${ }^{25}$

The same is ruled in the $A C I \mathrm{Adam}^{26}$ case: EU law must be interpreted as precluding national legislation, which does not distinguish the situation in which the source from which a reproduction for private use is made is lawful from that in which that source is unlawful.

\section{CONCLUSION}

Nowadays, the environment where authors' works are used has significantly changed, and it would be appropriate to change the copyright system so that it would suit better to interests and concepts of modern people. That way the copyright protection would be updated taking into consideration both the authors' interests and the information society's right to access the scientific and art accomplishments.

Copying of copyrighted work from any site on the Internet in a single copy for personal use without ensuring for the legality of the source, could be recognized as on this special occasion, when the rights of authors, performers and phonogram producers' could be legally restricted.

To achieve this, the Copyright Directive (2001/29/EC) should be amended with ability for Member States to restrict the author's exclusive making available rights, lowering them to the rights of receiving remuneration. Once the Copyright Directive had been amended, Member States' national legislation might impose additional restrictions on the rights of authors and additional duties for society to pay fair compensation.

The national legislations could be incorporated with provisions envisaging an obligation on part of Internet service providers to charge a fair fee from each user, that would allow him/her to reproduce (copy) the work for personal use, without ensuring the legality of source, but instead paying an additional "blank tape levy".

The balancing of author and neighboring rights subjects is to the

\footnotetext{
${ }^{25}$ Judgment of the Court (Fourth Chamber) of March 5, 2015, Case C-463/12. Copydan Båndkopi v. Nokia Danmark A/S.

${ }^{26}$ Judgment of the Court (Fourth Chamber) of April 10, 2014, Case C-435/12, ACI Adam BV and Others v. Stichting de Thuiskopie.
} 
benefit of all society-it provides the right for gifted people to receive the deserved remuneration and to pay taxes from it, as well as it lessens the possibilities of dishonest copyists of making shadow economics from illegally acquired resources.

Establishing balance among groups of rights holders make possible to secure observance of rights and circulation of funds which would allow, first of all, the rightholders to receive remuneration for their created intellectual product and the economy in general would benefit both in terms of taxes and GNP increase.

Piracy or the illegal use of intellectual property should be countered in all its forms of expression. However in the fight against piracy, one should not forget the individual's fundamental rights and the interests of the society in the information era. 